\title{
Penambahan Bovine Serum Albumin pada Pengencer Beltsville Thawing Solution terhadap Motilitas dan Daya Hidup Spermatozoa Babi Landrace
}

\author{
(THE ADDITION OF BOVINE SERUM ALBUMIN TO BELTSVILLE THAWING \\ SOLUTION DILUENTS AGAINST MOTILITY AND VITALITY OF LANDRACE PIGS \\ SPERMATOZOA)
}

I Made Agus Suryanatha ${ }^{1 *}$, Wayan Bebas ${ }^{2}$, Desak Nyoman Dewi Indira Laksmi ${ }^{2}$

${ }^{1}$ Dokter Hewan Praktik di Kabupaten Gianyar, Bali, Indonesia 80511; ${ }^{2}$ Laboratorium Reproduksi Veteriner, Fakultas Kedokteran Hewan, Universitas Udayana, Jl. PB Sudirman Denpasar, Bali, Indonesia 80225.

*Email: suryanathaagus@yahoo.co.id

\begin{abstract}
ABSTRAK
Penelitian ini bertujuan untuk mengetahui pengaruh penambahan berbagai konsentrasi bovine serum albumin (BSA) pada pengencer betsville thawing solution $(B T S)^{\circledR}$ dalam mempertahankan daya hidup dan motilitas spermatozoa babi Landrace. Penelitian ini menggunakan Rancangan Acak Lengkap (RAL) dengan empat perlakuan yaitu T0 (kontrol): yang diberikan BTS ${ }^{\circledR}$ tanpa BSA, T1: yang diberikan BTS $^{\circledR}$ ditambahkan BSA $5 \mathrm{mg} / \mathrm{ml}$, T2: yang diberikan BTS ${ }^{\circledR}$ ditambahkan BSA $10 \mathrm{mg} / \mathrm{ml}$ dan T3: yang diberikan BTS ${ }^{\circledR}$ ditambahkan BSA $20 \mathrm{mg} / \mathrm{ml}$. Setiap kombinasi perlakuan,diulang sebanyak lima kali, sehingga jumlah total sampel yang digunakan sebanyak 20 sampel. Variabel yang diukur dalam penelitian ini adalah daya hidup dan motilitas semen Hasil penelitian menunjukkan bahwa penambahan BSA pada pengencer BTS ${ }^{\circledast}$ dapat meningkatkan daya hidup dan motilitas spermatozoa babi Landrace. Konsentrasi yang optimal adalah $10 \mathrm{mg} / \mathrm{ml}$ dalam menjaga kestabilan dan menjaga tekanan osmosisnya agar tetap stabil.
\end{abstract}

Kata kunci: Bovine serum Albumin; Beltsville thawing solution; babi; pengencer; spermatozoa.

\begin{abstract}
This study aims to determine the effect of the addition of various bovine serum albumin (BSA) concentrations on betsville thawing solution $(B T S) \circledast$ extender to maintaining vitality and motility of spermatozoa on Landrace pigs. This study used Completely Randomized Design (CRD) with four treatments namely T0 (control): were given BTS ${ }^{\circledR}$ without BSA, T1: were given BTS ${ }^{\circledR}$ added BSA 5 $\mathrm{mg} / \mathrm{ml}$, T2: were given BTS ${ }^{\circ}$ added BSA $10 \mathrm{mg} / \mathrm{ml}$ and T3: were given BTS ${ }^{\circ}$ added BSA $20 \mathrm{mg} / \mathrm{ml}$. Each treatment combination was repeated five times, with the total sample used was 20 samples. The measured variables in this study were the vitality and motility of Landrace pig semen. The results showed that the addition of BSA to BTS ${ }^{\circledR}$ diluents could increase the vitality and motility of spermatozoa on Landrace pigs. Where the optimal concentration was $10 \mathrm{mg} / \mathrm{ml}$ in keeping stability and maintaining the osmosis pressure stable.
\end{abstract}

Keywords: Bovine Serum Albumin; Beltsville Thawing Solution; pig; extender; spermatozoa.

\section{PENDAHULUAN}

Daging merupakan sumber protein hewani yang bermutu tinggi dan dikonsumsi oleh masyarakat untuk memenuhi kebutuhan asam amino esensial tubuh. Daya beli konsumen yang meningkat mempengaruhi konsumen untuk memilih daging yang bermutu. Daging yang banyak dikonsumsi di Indonesia adalah daging ayam, sapi, domba, kambing dan babi (Agustina et al., 2017 ). Perkembangan produksi daging babi di Indonesia sejalan dengan tingkat perkembangan populasinya, dalam periode tahun 1990-1999 rata-rata produksi babi di Indonesia sebesar 152,4 ribu ton dengan peningkatan rata-rata 2,40 persen per tahun 
(Agustina et al., 2017 ${ }^{\mathrm{b}}$ ). Dilihat dari aspek produksi, ternyata Propinsi Bali menduduki urutan pertama. Daging babi terutama di Bali sangat diminati karena memiliki cita rasa yang enak disamping juga untuk keperluan upacara agama Hindu (Agustina et al., 2016 ${ }^{\mathrm{a}}$; 2016 ${ }^{\mathrm{b}}$ ). Pertambahan penduduk di Bali yang semakin meningkat tiap tahunnya menyebabkan konsumsi daging babi juga semakin meningkat. Oleh sebab itu pemotongan ternak babi di Bali setiap tahunnya terus mengalami peningkatan (Agustina et al., 2016 ${ }^{\mathrm{a}}$; Kariyasa, 2016).

Sejalan dengan upaya untuk meningkatkan mutu dan populasi maka penggunaan akan inseminasi buatan pada babi di masyarakat juga semakin banyak. Pengetahuan masyarakat dibidang peternakan babi sudah semakin maju dan dapat merasakan keuntungan dari penggunaan inseminasi buatan (IB) dalam meningkatkan efisiensi reproduksi ternak (Glossop, 2001).

Menurut The'rien et al. (1999), saat ini dalam upaya pelayanan IB pada babi, inseminator di desa masih menggunakan semen segar yaitu semen yang ditampung dari pejantan unggul yang ditempatkan dalam botol kemudian dibawa kelapangan untuk pelayanan IB. Penggunaan semen segar tanpa proses pengenceran mempunyai banyak kelemahan. Semen segar cepat sekali mengalami penurunan kualitas seperti: paparan yang terus menerus protein plasma semen dengan spermatozoa. Keadaan ini dapat merusak membran plasma spermatozoa serta penurunan motilitas dan daya hidup spermatozoa. Hal ini terjadi karena plasma semen segar babi mengandung protein yang dapat menimbulkan pengaruh buruk terhadap membran plasma sel spermatozoa akibat bereaksi dengan lipid penyusun membran plasma sel.

Semen babi mengandung spermatozoa yang mempunyai komposisi membran plasma yang berbeda dibanding ternak lainnya yaitu memiliki sphingomyelin dan phosphatidylethanolamine yang sangat tinggi hingga mencapai $14 \%$ dan $24 \%$. Kondisi ini menyebabkan mudah mengalami serangan cold shock (Paulenz et al., 2000). Oleh karena itu penambahan bahan pengencer yang tepat akan menjaga kualitas spermatozoa dari serangan cold shock.

Pengencer Beltsville Thawing Solution $\left(\right.$ BTS $\left.^{\circledR}\right)$ adalah bahan pengencer berdaya simpan 1-3 hari (Gadea, 2003). Dilihat dari komposisinya, BTS $^{\circledR}$ belum mempunyai kandungan bahan yang mampu memproteksi sel spermatozoa terhadap serangan radikal bebas yang sering juga disebut Reactive Oxygen Species (ROS). Terbetuknya ROS dari aktivitas metabolisme sel selama prosesing semen itu berlangsung (Chatterjee et al., 2001).

Bovine Serum Albumin (BSA) merupakan salah satu protein yang mempunyai kandungan protein yang berlimpah dalam plasma dengan konsentrasi $5 \mathrm{~g} / 500 \mathrm{ml}$. Di samping itu, BSA mempunyai komposisi asam amino sebanyak 20 macam (Friedli, 2006). Dengan penambahan berbagai konsentrasi BSA pada bahan pengencer kandungan asam amino atau plasma protein pada semen yang telah diencerkan diharapkan mampu mensubstitusi penurunan konsentrasi berbagai bahan yang terdapat di dalam plasma semen akibat proses pengenceran, sehingga dapat menjaga stabilitas membran sel spermatozoa (Gadea, 2003).

Penelitian ini bertujuan mengetahui pengaruh penambahan berbagai konsentrasi BSA pada pengencer BTS $^{\circledR}$ dalam mempertahankan daya hidup dan motilitas spermatozoa babi Landrace. Sehingga ketersediaan semen dapat terpenuhi setiap saat, dalam upaya peningkatan mutu dan populasi ternak babi untuk menunjang program pemerintah dalam memenuhi kebutuhan daging nasional.

\section{METODE PENELITIAN}

Hewan coba yang digunakan dalam penelitian ini adalah satu ekor babi jantan 
jenis Landrace dengan umur \pm 2 tahun sebagai sampel. Langkah yang pertama dilakukan yaitu membuat pengencer BTS ${ }^{\circledR}$. Pengencer BTS $^{\circledR}$ dibuat dengan cara melarutkan serbuk BTS ${ }^{\circledR}$ (50 gram) yang dimasukkan ke tabung Erlenmeyer yang berisi 1.000 mililiter aqua destilata, digoyang-goyangkan sampai homogen, kemudian dimasukkan ke inkubator dengan suhu $37^{\circ} \mathrm{C}$ selama 15 menit. Kemudian dilanjutkan membuat perlakuan yaitu membuat BSA Pembuatan $\mathrm{T}_{1}$ dengan cara menambahkan konsentrasi BSA $5 \mathrm{mg} / \mathrm{ml}$ kedalam pengencer BTS $^{\circledR}$, kemudian $\mathrm{T}_{2}$ dengan cara menambahkan konsentrasi BSA $10 \mathrm{mg} / \mathrm{ml}$ kedalam pengencer BTS $^{\circledR}$ dan $\mathrm{T}_{3}$ menambahkan konsentrasi BSA $20 \mathrm{mg} / \mathrm{ml}$ kedalam pengencer BTS ${ }^{\circledR}$. Teknik penampungan semen dilakukan dengan menggunakan metode massage (pijatan). Penampungan semen dilakukan dengan cara memasukan babi jantan ke ruangan yang di dalamnya terdapat dummy (betina buatan yang digunakan umtuk pengambilan semen). Babi dibiarkan menggosokkan badannya pada dummy. Setelah pejantan naik ke dummy, dilakukan metode pijatan jika gland penisnya sudah keluar, penis dipegang dengan menggunakan tiga jari dan dua jari tangan lainnya untuk merangsang ujung penis. Pada saat penis telah ereksi maksimal, pejantan akan mengeluarkan semen. Cairan bening yang pertama keluar harus dibuang karena tidak mengandung sperma (fraksi pertama), kemudian jika sudah terlihat cairan berwarna putih (fraksi kedua) baru kemudian semen ditampung di dalam tabung yang sudah dimodifikasi yang di dalamnya terdapat tabung Erlenmeyer, cerobong air, kain kasa dan karet. Pemeriksaan semen dilakukan secara makroskopis dan mikroskopis. Penilaian semen secara makroskopis meliputi volume, bau, warna, konsistensi, derajat keasaman $(\mathrm{pH})$ semen. Sedangkan secara mikroskopis yaitu motilitas, abnormalitas, dan konsentrasi spermatozoa. Menghitung konsentrasi spermatozoa dengan menggunakan haemocytometer, caranya seperti menghitung sel darah merah (eritrosit). Kotak arah diagonal atau empat kotak ditiap sudut dan satu kotak ditengah, hasil perhitungan tersebut dikalikan dengan 10 juta sama dengan konsentrasi spermatozoa per ml pengenceran semen dilakukan dengan memasukkan semen kedalam bahan pengencer BTS ${ }^{\circledR}$. Dengan satu dosis IB mempunyai konsentrasi spermatozoa $3 \times 10^{9}$ dalam $80 \mathrm{ml}$. Dalam penelitian ini, semen yang telah diencerkan disimpan di ice pack selama 72 jam. Pengamatan terhadap daya hidup spermatozoa dilakukan dengan menggunakan pewarnaan eosin negrosin sitrat. Sampel diambil 1 tetes $(0,05 \mathrm{ml})$ yang diteteskan pada object glass kemudian ditambah eosin negrosin sitrat 2 tetes selanjutnya dibuat preparat hapusan dan diangin-anginkan sampai kering, kemudian preparat diperiksa di bawah mikroskop untuk menghitung jumlah spermatozoa yang masih utuh beserta membran plasma utuhnya. Penilaian dilakukan dengan system skor $0 \%$ sampai $100 \%$ (Toelihere, 1993). Presentase hidup (\%) adalah presentase spermatozoa yang hidup dihitung dan dievaluasi menggunakan zat pewarna eosin negrosin sitrat. Spermatozoa yang hidup tidak berwarna, sedangkan yang mati akan berwarna merah. Pemeriksaan persentase motilitas spermatozoa yaitu dengan cara mengambil semen yang telah diencerkan yang diambil menggunakan spuit dan diletakkan pada object glass kemudian ditutup dengan cover glass dan diamati dengan mikroskop dengan perbesaran 400x untuk menghitung persentase jumlah spermatozoa yang bergerak progresif.

Penelitian ini menggunakan Rancangan Acak Lengkap (RAL) dengan 4 perlakuan yaitu T0: dengan menggunakan pengencer $\mathrm{BTS}^{\circledR}$ tanpa BSA, T1: pengencer $\mathrm{BTS}^{\circledR}$ ditambah BSA $5 \mathrm{mg} / \mathrm{ml}$, T2: pengencer BTS $^{\circledR}$ ditambah BSA $10 \mathrm{mg} / \mathrm{ml}$, T3: pengencer BTS ${ }^{\circledR}$ ditambah BSA $20 \mathrm{mg} / \mathrm{ml}$. 
Setiap kombinasi perlakuan diulang sebanyak lima kali, sehingga jumlah total sampel yang digunakan sebanyak 20 sampel. Data yang dikumpulkan dalam penelitian ini berupadaya hidup dan motilitas semen babi Landrace yang dilakukan selama 72 jam dimulai saat penyimpanan. Penelitian ini dilakukan di sentra pembibitan Baturiti, Tabanan dan di Laboratorium Reproduksi Veteriner Tabel 1. Hasil pemeriksaan mikroskopis dan makroskopis semen segar babi Landrace.

\begin{tabular}{llc}
\hline & Kualitas semen babi Landrace & \\
\hline & Kekentalan semen & Normal \\
Pemeriksaan & Warna semen & Putih krem \\
makroskopis & Volume semen (ml) & 170 \\
& Keasaaman/Ph & 7 \\
& Bau & Khas semen babi \\
\hline & Gerakan massa & +++ \\
Pemeriksaan & Konsentrasi $(10 \% \mathrm{ml})$ & 790 \\
mikroskopis & Pergerakan progresif $(\%)$ & $85 \mathrm{P}$ \\
& Spermatozoa hidup $(\%)$ & 96 \\
& Abnormalitas spermatozoa $(\%)$ & 4,0 \\
\hline
\end{tabular}

Keterangan: +++: Gerakan gelombang massa baik; P: Gerakan individu sperma maju dan cepat.

Tabel 2. Rerata daya hidup spermatozoa babi Landrace yang disimpan selama 72 jam.

\begin{tabular}{cc}
\hline Perlakuan & Rerata \pm SD \\
\hline T0 & $89,40 \pm 1,140^{\mathrm{b}}$ \\
T1 & $92,60 \pm 1,140^{\mathrm{c}}$ \\
T2 & $94,60 \pm 0,548^{\mathrm{d}}$ \\
T3 & $86,00 \pm 1,000^{\mathrm{a}}$ \\
\hline
\end{tabular}

Keterangan: Huruf superskrip yang berbeda menyatakan perbedaan nyata taraf $\mathrm{P}<0,05$

Penambahan konsentrasi BSA 5 $\mathrm{mg} / \mathrm{ml}, 10 \mathrm{mg} / \mathrm{ml}$ dan $20 \mathrm{mg} / \mathrm{ml}$ kedalam pengencer BTS $^{\circledR}$ berpengaruh nyata $(\mathrm{P}<0,05)$ terhadap daya hidup dan motilitas spermatozoa babi Landrace. Hasil analisis daya hidup spermatozoa babi Landrace yang diberi perlakuan penambahan konsentrasi $B S A 5 \mathrm{mg} / \mathrm{ml}, 10 \mathrm{mg} / \mathrm{ml}$ dan 20 $\mathrm{mg} / \mathrm{ml}$ kedalam pengencer BTS ${ }^{\circledR}$ selama 72 jam disajikan pada Tabel 2. Dimana perlakuan T0 mempunyai daya hidup spermatozoa yang lebih rendah $(\mathrm{P}<0,05)$ dari T1, T2, dan daya hidup spermatozoa yang lebih tinggi dari T3. Perlakuan T1 memiliki daya hidup lebih rendah $(\mathrm{P}<0,05)$
Fakultas Kedokteran Hewan Universitas Udayana pada bulan Mei 2018.

\section{HASIL DAN PEMBAHASAN}

Hasil pemeriksaan mikroskopis dan makroskopis semen segar babi Landrace tampak pada Tabel 1. Hasil pemeriksaan semen segar babi Landraces secara makroskopis dan mikroskopis layak digunakan dan diproses lebih lanjut untuk proses pengenceran. 
spermatozoa yang lebih tinggi dari T3. Perlakuan T1 memiliki daya hidup lebih rendah $(\mathrm{P}<0,05)$ dengan $\mathrm{T} 2$ dan daya hidup spermatozoa lebih tinggi dari T0 dan T3. Perlakuan T2 daya hidup spermatozoa lebih tinggi $(\mathrm{P}<0,05)$ dibandingkan dengan $\mathrm{T} 0$, T1, dan T3. Perlakuan T3 daya hidup spermatozoa lebih rendah $(\mathrm{P}<0,05)$ dari $\mathrm{T} 0$, T1, dan T2.

Pada perlakuan T2 yaitu penambahan BSA $10 \mathrm{mg} / \mathrm{ml}$ kedalam pengencer BTS ${ }^{\circledR}$ selama 72 jam memiliki daya hidup dan motilitas spermatozoa yang paling tinggi. Hal ini terjadi karena penambahan BSA sebanyak $10 \mathrm{mg} / \mathrm{ml}$ merupakan konsentrasi yang efektif.Konsentrasi pengencer yang efektif dapat membantu menjaga kestabilan spermatozoa dan menjega tekanan osmosisnya agar tetap stabil (Gadea, 2003). Demikian pula, pada perlakuan T1 yaitu penambahan BSA $5 \mathrm{mg} / \mathrm{ml}$ kedalam pengencer BTS $^{\circledR}$ selama 72 jam masih dapat meningkatkan daya hidup dan motilitas spermatozoa babi Landrace. Hal ini dikarenakan tekanan osmosis sel masih stabil, sehingga dapat menjaga stabilitas spermatozoa akan tetapi masih belum efektif. Sedangkan penambahan BSA pada konsentrasi $20 \mathrm{mg} / \mathrm{ml}$ memiliki pengaruh nyata $(\mathrm{P}<0,05)$ dalam menurunkan daya hidup dan motilitas spermatozoa babi Landrace. Hal ini disebabkan penambahan $20 \mathrm{mg} / \mathrm{ml}$ BSA pada pengencer BTS $^{\circledR}$ adalah konsentrasi BSA yang tinggi yang dapat menyebabkan osmolaritas sel tinggi sehingga larutan berubah menjadi Hipertonik.

Penambahan BSA memiliki fungsi sebagai antioksidan dan krioprotektan sehingga mampu mensubstitusi penurunan konsentrasi berbagai bahan yang terkandung dalam plasma semen selama proses pengenceran, sehingga dapat menjaga stabilitas membran sel semen (Gadea, 2003). Akan tetapi jika penambahan BSA dengan konsentrasi yang lebih tinggi akan menyebabkan osmolaritas selnya tinggi sehingga larutan berubah menjadi hipertonik.

\section{SIMPULAN}

Dari hasil penelitian ini dapat disimpulkan bahwa penambahan konsentrasi BSA pada pengencer BTS $^{\circledR}$ berpengaruh nyata dalam mempertahankan daya hidup dan motilitas spermatozoa babi Landrace, dimana konsentrasi yang terbaik adalah $10 \mathrm{mg} / \mathrm{ml}$.

\section{SARAN}

Perlu dilakukan penelitan lebih lanjut untuk mengetahui fertilitas semen yang disimpan menggunakan pengencer BTS $^{\circledR}$ dengan penambahan BSA dengan konsentrasi $10 \mathrm{mg} / \mathrm{ml}$.

\section{UCAPAN TERIMAKASIH}

Penulis mengucapkan banyak terima kasih kepada dosen pembimbing, serta pembibitan Baturiti, Tabanan dan Laboratorium Reproduksi Veteriner Fakultas Kedokteran Hewan Universitas Udayana yang telah memfasilitasi penelitian ini serta keluarga maupun temanteman yang telah membantu dalam proses penulisan dan penelitian.

\section{DAFTAR PUSTAKA}

Agustina KK, Wirata IW, Dharmayudha AAGO, Kardena IM, Dharmawan NS. $2016^{\mathrm{a}}$. Increasing farmer income by improved pig management systems. Bul. Vet. Udayana. 8: 122-127.

Agustina KK., Dharmayudha AAGO, Oka IBM, Dwinata IM, Kardena IM, Dharmawan NS, Damriyasa IM. 2016 ${ }^{\text {b }}$. Case of entamoebiasis in pigs raised with a free range systems in Bali, Indonesia. J. Vet. 17: 570-575.

Agustina KK, Sari PH, Suada IK. 2017 ${ }^{\text {a }}$ Pengaruh perendaman pada infusa daun salam terhadap kualitas dan daya tahan daging babi. Bul. Vet. Udayana. 9(1): 34-41.

Agustina KK, Swacita IBN, Oka IBM, Dwinata IM, Traub RJ, Cargill C, Damriyasa IM. 2017. Reducing zoonotic and internal parasite burdens 
in pigs using a pig confinement system. Vet. World. 10(11): 1347-1352.

Chatterjee S, De Lamirande E, Gagnon. 2001. Cryopreservation alters membrane sulfhydryl status of bull spermatozoa: Protection by oxidized glutathione. Mol. Reprod. Dev. 60: 498506.

Friedli GL. 2006. Interaction Of SWP With Bovine Serum Albumin (BSA) http://www.friedli.com/research/PhD/ chapter5.html (Tanggal akses 20 April 2011)

Gadea J. 2003. Pig industry-semen extenders used in the artificial insemination of swine. A review. Spanish J. Agric. Res. 1(27): 17-27.

Glossop CE. 2001. AI and its influenceon production efficiency, pork-production agricultural and food. Malmesbury, Wiltshire, England.
Kariyasa. 2016. Analisis penawaran dan permintaan serta potensi ekspor daging babi di Indonesia. http://media.neliti.com/media/publicati ons/43906-ID-analisis-penawarandan-permintaan=daging-sapi-diindonesia-sebelum-dan-saat-kris.pdf (Tanggal akses 2 April 2018)

Paulenz H, Kommisrud E, Hofmo PO. 2000. Effect of long-term storage at different temperatures on the quality of liquid boar semen. Repord. Dom. Anim. 35: 83-85.

The'rien I, Moreau R, Manjunath P. 1999. Major proteins of bovine seminal plasma andhigh-density lipoprotein Induce cholesterolefûux from epididymal sperm. Biol. Reprod. 59: 768-776. 